\title{
THE PREVALENCE OF ARTERIAL HYPERTENSION AMONG STUDENTS OF WEST POMERANIAN VOIVODESHIP
}

\author{
Danuta Umiastowska, ${ }^{1, A, B, C, D}$ Hanna Żółtowska ${ }^{2, A, B}$ \\ 1 Faculty of Physical Culture and Health Promotion, University of Szczecin, Poland \\ ${ }^{2}$ Wojewódzki Zespół Szkół Policealnych Szczecin, Poland

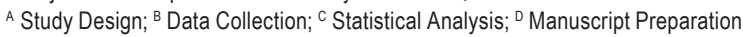

\section{Address for corpespondence:} \\ Danuta Umiastowska \\ Univeristy of Szczecin, Faculty of Physical Culture and Health Promotion \\ Al. Piastów 40b, building 6, 71-065 Szczecin, Poland \\ E-mail: danuta_umiastowska@univ.szczecin.pl
}

\begin{abstract}
Ahstract. The research was carried out as part of the research project N N 404260335 "The lifestyle of children and adolescents and their level of athleticism, fitness and somatic development" during Crampton test in 2633 students of elementary, secondary and high schools in West Pomeranian Voivodeship. 214 subjects, that is $8.1 \%$ of the whole group, were qualified for the group with the hypertension. The arterial hypertension was reported in $7.9 \%$ of girls and $8.4 \%$ of boys. The statistically significant dependencies between the prevalence of arterial hypertension and the size of metropolitan area where the children and adolescents live, as well as their sex were observed.
\end{abstract}

KeV Wordls: hypertension, children, adolescents

\section{Introduction}

Among the factors favorable for the development of arterial hypertension among children and adolescents the most common are: genetic factors, low birth weight, excessive consumption of salt, obesity and insufficient physical activity. Untreated or irregularly or ineffectively treated arterial hypertension leads to the occurence of changes in most of the organs (for instance, heart, brain, kidneys, eyes) and tissues. The problem of the prevalence of hypertension is an urgent issue which can be testified by the formulation of Guidelines for the management of arterial hypertension published in 2013 by the European Society of Hypertension (ESH) and European Society of Cardiology (ESC) which are the continuation of the previously issued guidelines (in the years 2003 and 2007) (Wytyczne... 2013). The hypertension among children and adolescents is understood as an average systolic or diastolic blood pressure on three independent occasions equal or higher than the 95th percentile appropriate for the sex, age and height (Lurbe et al. 2009). The phenomenon is defined in subsequent stages of ontogeny, that is: prehypertension, stage 1 hypertension and stage 2 hypertension. Prehypertension includes the systolic 
or diastolic blood pressure that is greater than or equal to the 90th percentile, but less than the 95th percentile, in adolescents BP > 120/80 mm Hg, even if the value is less than 90th percentile. The control measurement should be taken after 6 months. In stage 1 hypertension systolic or diastolic blood pressure is between the 95th percentile and the 99th percentile plus $5 \mathrm{mmHg}$. The control measurement should be repeated with an interval of 1-2 weeks. Pharmacological treatment is implemented in case of the prevalence of secondary hypertension. Stage 2 hypertension is in the range >99th percentile plus $5 \mathrm{mmHg}$. The diagnostic procedure in this case should take place immediately. In case of overweight people the weight loss, taking up physical activity and a proper diet are advisable (Chobanian 2003; The Fourth Report... 2004).

\section{Material and methods}

The research was carried out as part of the research project N N 404260335 "The lifestyle of children and adolescents and their level of athleticism, fitness and somatic development" in the years 2008-2011. The aim of the research project was to create positive attitudes of children and adolescents towards participation in physical activities, as well as to promote the "healthy lifestyle". Two parallel types of actions were taken:

- diagnostic, aiming at identifying the level of athleticism, somatic development and fitness, as well as eating habits, participation in physical activities and healthy attitudes among subjects of the research,

- educational, aiming at preparing the environments influencing students to create their healthy attitudes and habits.

The blood pressure measurements were taken in a supine position after 10 minutes of the patient lying flat and they were implemented as part of the Crampton test. Among the subjects, in whom high blood pressure was registered a second time, a control measurement was taken to confirm the result excluding any measurement errors. A countercheck of the measurement was carried out twice without doing the Crampton test. It was carried out in 1-week and 4-week intervals after the first measurement. Only those measurements which were positively confirmed were included in the research. It allowed to avoid various factors conditioning invalid measurement, for instance, the white coat syndrome, temporary indisposition of the student etc. Qualification for a group with hypertension has been prepared according to the tables elaborated by A. Krzyżaniak, M. Krzywińska-Wiewiorowska, B. StawińskaWitoszyńska and others (Krzyżaniak et al. 2009).

2633 students of elementary, secondary and high schools at the age of $8,9,11,12,14,15$ and 17 from big cities, small towns and villages of West Pomeranian Voivodeship were included in the research.

\section{Results}

The results of the research are presented in the Tables 1-5 and in Figure 1.

The size of metropolitan area differentiates in a statistically important way the percentage of children with arterial hypertension in a given population:

- for villages and small towns-structure index $z_{\alpha=0,05}=1.96<z=2.87$,

- for villages and big cities-structure index $z_{a=0,05}=1.96<z=3.14$,

- for small towns and big cities-structure index $z_{a=0,05}=1.96<z=2.54$. 
Table 1. Prevalence of arterial hypertension in girls

\begin{tabular}{ccccc}
\hline \multirow{2}{*}{ Age } & \multicolumn{2}{c}{ Norm } & \multicolumn{2}{c}{ Hypertension } \\
\cline { 2 - 5 } & $\mathrm{n}$ & $\%$ & $\mathrm{n}$ & $\%$ \\
\hline 8 & 107 & 9.1 & 5 & 5.0 \\
9 & 205 & 17.4 & 21 & 20.8 \\
11 & 144 & 12.2 & 9 & 8.9 \\
12 & 178 & 15.1 & 13 & 12.9 \\
14 & 115 & 9.8 & 11 & 10.9 \\
15 & 102 & 8.7 & 3 & 3.0 \\
17 & 328 & 27.8 & 39 & 38.6 \\
\hline Total & 1179 & 100.0 & 109 & 100.0 \\
\hline
\end{tabular}

Source: author's own research.

Table 2. Prevalence of arterial hypertension in boys

\begin{tabular}{rrrrr}
\hline \multirow{2}{*}{ Age } & \multicolumn{2}{c}{ Norm } & \multicolumn{2}{c}{ Hypertension } \\
\cline { 2 - 5 } & $\mathrm{n}$ & $\%$ & $\mathrm{n}$ & $\%$ \\
\hline 8 & 173 & 14.0 & 14 & 12.4 \\
9 & 240 & 19.4 & 15 & 13.3 \\
11 & 159 & 12.8 & 14 & 12.4 \\
12 & 183 & 14.8 & 13 & 11.5 \\
14 & 153 & 12.3 & 21 & 18.6 \\
15 & 89 & 7.2 & 8 & 7.1 \\
17 & 243 & 19.6 & 28 & 24.8 \\
\hline Total & 1240 & 100.0 & 113 & 100.0 \\
\hline
\end{tabular}

Source: author's own research.

Table 3. . Prevalence of arterial hypertension in all the subjects

\begin{tabular}{ccccc}
\hline \multirow{2}{*}{ Age } & \multicolumn{2}{c}{ Norm } & \multicolumn{2}{c}{ Hypertension } \\
\cline { 2 - 5 } & $\mathrm{n}$ & $\%$ & $\mathrm{n}$ & $\%$ \\
\hline 8 & 280 & 11.6 & 19 & 8.9 \\
9 & 445 & 18.4 & 36 & 16.8 \\
11 & 303 & 12.5 & 23 & 10.7 \\
12 & 361 & 14.9 & 26 & 12.1 \\
14 & 268 & 11.1 & 32 & 15.0 \\
15 & 191 & 7.9 & 11 & 5.1 \\
17 & 571 & 23.6 & 67 & 31.3 \\
\hline Total & 2419 & 100.0 & 214 & 100.0 \\
\hline
\end{tabular}

Source: author's own research. 
Table 4. Group size according to the size of the metropolitan area

\begin{tabular}{lcccccc}
\hline \multirow{2}{*}{$\begin{array}{l}\text { Size of the metropolitan } \\
\text { area }\end{array}$} & \multicolumn{2}{c}{ Norm } & \multicolumn{2}{c}{ Hypertension } & \multicolumn{2}{c}{ All the subjects } \\
\cline { 2 - 7 } & girls & boys & girls & boys & girls & boys \\
\hline Village & 114 & 156 & 17 & 13 & 131 & 169 \\
Small town & 607 & 680 & 42 & 60 & 649 & 740 \\
Big city & 458 & 404 & 42 & 40 & 500 & 444 \\
All together & 1179 & 1240 & 101 & 113 & 1280 & 1353 \\
\hline Total & 2419 & \multicolumn{3}{c}{214} \\
\hline
\end{tabular}

Source: author's own research.

Table 5. The proportion of subjects with normal blood pressure and hypertension according to the size of metropolitan area [\%]

\begin{tabular}{lllllll}
\hline \multirow{2}{*}{$\begin{array}{l}\text { Size of the metropolitan } \\
\text { area }\end{array}$} & \multicolumn{2}{c}{ Norm } & \multicolumn{2}{c}{ Hypertension } & \multicolumn{2}{c}{ All the subjects } \\
\cline { 2 - 7 } & girls & boys & girls & boys & girls & boys \\
\hline Village & 38.0 & 52.0 & 5.7 & 4.3 & 43.7 & 56.3 \\
Small town & 43.7 & 49.0 & 3.0 & 4.3 & 46.7 & 53.3 \\
Big city & 48.5 & 42.8 & 4.4 & 4.2 & 53.0 & 47.0 \\
\hline
\end{tabular}

Source: author's own research.

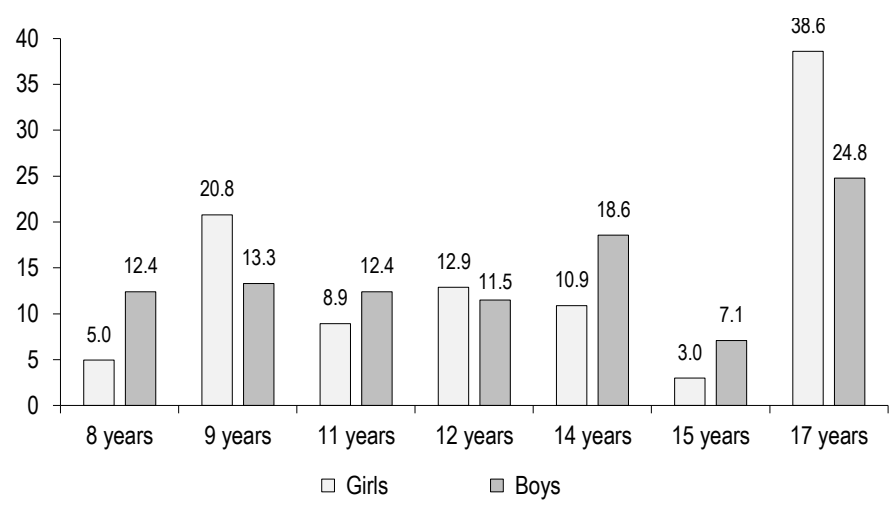

Figure 1. Differentiation of the prevalence of hypertension according to the sex of the subjects [\%]

Source: author's own research.

Sex and size of the metropolitan area does not differentiate in a statistically significant way the percentage of subjects with hypertension in the group of boys (structure index $z_{a=0,05}=1.96>z=0.82 ; z=0.76 ; z=0.61$ ). 
However, as far as girls from different metropolitan areas are concerned, the differences become statistically significant:

- for villages and small towns-structure index $z_{a=0,05}=1.96<z=2.07$,

- for villages and big cities-structure index $z_{\alpha}=0.05=1.96<z=2.55$,

- for small towns and big cities-structure index $z_{a=0,05}=1.96<z=2.37$.

The age of the subjects differentiates in a statistically important way the percentage of subjects with arterial hypertension (structure index $z_{a=0,05}=1.96<z=2.46$ ).

214 subjects were qualified for the arterial hypertension group which constituted $8.1 \%$ of the whole group. Among the subjects arterial hypertension was recorded in $7.9 \%$ of girls and $8.4 \%$ of boys.

Taking into account the size of the metropolitan area in which the subjects live, the highest percentage of the subjects with arterial hypertension was recorded in 17-year-old girls and boys from big cities and 9-year-old girls from villages.

No cases of arterial hypertension have been observed in 11-year-old girls from villages and 11-year-old boys from big cities as well as 12-year-old boys from villages.

\section{Conclusions}

A. Januszkiewicz claims that primary arterial hypertension occurs at a young age notably more often that it has been believed. Basing on research, 35\% of young people aged $12-18$ and $3 \%$ of children aged $7-11$ have been diagnosed with hypertension.

A connection is sought between this fact and the cardiovascular risk factors such as obesity or lipid disorders. The prevalence of arterial hypertension in the families of the subjects is also of a considerable importance. E. Lubre seeks the causes of hypertension in youth in the prevalence of obesity and the condition left untreated can lead in consequence to complications in heart and kidneys functions (Lubre 2010). The research carried out constitutes a valid diagnosis of the conditions recorded in the research project. Indicating the prevalence of changes in functioning of organisms of children and adolescents has been reported to parents and noted down in school files.

Basing on the statistical analysis of the results it has been observed that:

1. The most numerous group of subjects with arterial hypertension were 17 -year-old girls $(38.6 \%)$ and 17 -year-old boys (24.8\%).

2. The size of metropolitan area is a factor differentiating the prevalence of hypertension in girls.

3. The prevalence of arterial hypertension is the most visible in students from big cities.

\section{Refepences}

Chobanian A.V., Bakris G.L., Black H.R., Cushman W.C., Green L.A., Izzo J.L., Jones D.W., Materson B.J., Oparil S., Wright J.Tjr., Roccella E.J. The seventh report of the joint national committee on prevention, detection, evaluation, and treatment of high blood pressure: the JNC 7 report. JAMA. 2003; 289: 2560-2572.

Januszkiewicz A. Nadciśnienie tętnicze u dzieci. Medycyna Praktyczna. 2002, www.mp.pl/artykuly/13183.

Krzyżaniak A., Krzywińska-Wiewiorowska M., Stawińska-Witoszyńska B., Blood pressure references for Polish children and adolescents. J. of Pediatrics, 2009; 168: 1335-1342.

Lurbe E., Cifkova R., Cruickshank J.K., Dillon M.J., Ferreira I, Invitti C, Kuznetsova T. Management of high blood pressure in children and adolescents: recommendations of the European Society of Hypertension. J Hypertens, 2009; 27: 1719-1742. 
Lurbe E. Hypertension in children and adolescents. European Society of Hypertension Scientific Newsletter: Update on Hypertension Management. 2010; 11 (13). Translation: A. Święcicka [IN]: Choroby Serca i Naczyń 2010; 7, 3: 107-111.

The Fourth Report on the Diagnosis, Evaluation, and Treatment of High Blood Pressure in Children and Adolescents, National High Blood Pressure Education Program Working Group on High Blood Pressure in Children and Adolescents. PEDIATRICS. 2004; 114, Suppl. 2 (1): 555-576.

Wytyczne ESH/ESC dotyczące postępowania w nadciśnieniu tętniczym w 2013 roku, Grupa Robocza Europejskiego Towarzystwa Nadciśnienia Tętniczego (ESH) i Europejskiego Towarzystwa Kardiologicznego (ESC) do spraw postępowania w nadciśnieniu tętniczym. Kardiologia Polska. 2013; 71, Supl. III: 27-118, www.kardiologia.pl.

Cite this article aS: Umiastowska D., Żółtowska H. The Prevalence of Arterial Hypertension among Students of West Pomeranian Voivodeship. Central European Journal of Sport Sciences and Medicine. 2015; 11 (3): 81-86. 